\title{
Activity of aspirin analogues and vanillin in a human colorectal cancer cell line
}

\author{
JOLLY DEB, HARPREET DIBRA, SONG SHAN, SUJTTH RAJAN, JAINABA MANNEH, \\ CHANDRA S. KANKIPATI, CHRIS J. PERRY and IAIN D. NICHOLL
}

\author{
School of Applied Sciences, University of Wolverhampton, Wolverhampton WV1 1LY, UK
}

Received February 22, 2011; Accepted April 19, 2011

DOI: $10.3892 /$ or.2011.1320

\begin{abstract}
Colorectal cancer is the third most common cancer and is associated with significant morbidity and mortality. Epidemiological and animal studies indicate that regular acetylsalicylic acid (aspirin) intake is associated with a reduction in the incidence of colorectal cancer. Acetylsalicylic acid (ASA) has also been shown to inhibit colorectal cancer cell proliferation in vitro. The molecular basis for this specific cytotoxicity is an area of considerable debate. To investigate the toxicity of salicylates, the sensitivity of the DNA mismatch repair proficient SW480 human colorectal cancer cell line to four categories of compounds with varying degrees of structural similarity to acetylsalicylic acid was tested. These compounds were: i) salicylic acid analogues with substituents at the 5-position; ii) ASA analogues with extended chain lengths in the acyl group; iii) vanillin (4-hydroxy-3-methoxybenzaldehyde; and iv) bis(2-carboxyphenyl) succinate (BCS) and structurally similar derivatives thereof. It was found that compounds with amino and acetamido substituents at the salicylate 5-position were less toxic than ASA itself. Modifications to the length of the hydrocarbon chain in the acyl groups of ASA analogues also marginally reduced toxicity. Vanillin exhibited relatively limited toxicity against the SW480 colorectal cancer cell line. Commercially available and in-house synthesised BCS (diaspirin) were notably more inhibitory to cell growth than ASA itself, yet retained substantial specificity against colorectal cancer cell lines vs. non-colorectal cancer cell lines. BCS and ASA were toxic to SW480 cells through initiation of necrotic and apoptotic pathways. Fumaroyldiaspirin and benzoylaspirin exhibited
\end{abstract}

Correspondence to: Dr Iain D. Nicholl, Research Institute in Healthcare Science, School of Applied Sciences, University of Wolverhampton, Wulfruna Street, Wolverhampton WV1 1LY, UK

E-mail: i.nicholl@wlv.ac.uk

Abbreviations: ASA, acetylsalicylic acid; BCS, bis(2-carboxyphenyl) succinate, diaspirin; CRC, colorectal cancer; MTT, 3-(4,5-dimethylthiazol-2-yl)-2,5-diphenyltetrazolium bromide; NSAIDs, non-steroidal anti-inflammatory drugs

Key words: aspirin, aspirin analogues, diaspirin, colorectal cancer greater toxicity than ASA against the SW480 cell line. A novel method for synthesis of BCS, a compound that has erratic commercial availability, is described. We propose that the anti-inflammatory and anticancer capacity of BCS and the other analogues described herein is worthy of investigation.

\section{Introduction}

There is abundant epidemiological and experimental evidence that regular ingestion of non-steroidal anti-inflammatory drugs (NSAIDs) including aspirin (ASA) promotes colorectal tumour regression and reduces the relative risk of developing colorectal cancer (1-6). There is also substantial evidence that ASA is specifically cytotoxic against colorectal cancer (CRC) cells cultured in vitro (7). However, gastrointestinal and renal disturbances preclude the universality of ASA as a chemopreventative agent, and so much effort has gone into the synthesis of novel NSAID derivatives which retain antineoplastic activities with minimal side effects (8).

Rather surprisingly, the molecular basis for the antiproliferative effect of NSAIDs, including ASA, in colorectal cancer cells is deeply controversial, with a range of theories in circulation (reviewed in ref. 9). Mechanistically NSAIDs can, for example, i) inhibit cyclooxygenases (COX) $(7,10)$, ii)

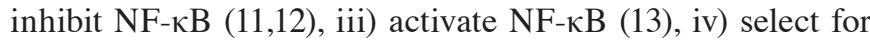
microsatellite stability (14), v) down-regulate BCL-2 expression (15), vi) up-regulate BAX (16) or XRCC3 expression (17), vii) inhibit protein phosphatase $2 \mathrm{~A}(18)$ and viii) induce expression of the DNA mismatch repair proteins hMLH1, hMSH2, hMSH6 and hPMS2 in DNA MMR proficient cells, which ultimately facilitates apoptosis (programmed cell death) (19).

To gain insight into ASA-based cytoxicity we sought to investigate the capacity of several modified salicylates and vanillin to inhibit the growth of SW480 CRC cells, as a prelude to investigation of any possible structure/activity relationships. The SW480 adenocarcinoma cell line is DNA mismatch repair competent with a mutant p53 status [and is COX-2negative (20)] and is thus a good in vitro model for this purpose. Salicylic acid derivatives modified at the 5-position or with altered acyl group chain lengths were somewhat less toxic than ASA; however, we found that bis(2-carboxyphenyl) succinate and derivatives were significantly more toxic than ASA, and this toxicity was noticeably greater in cell lines with CRC origin. 
Table I. Properties of the alkanoyl salicylates prepared.

\begin{tabular}{lccccc}
\hline $\mathrm{X}($ Fig. 1B) & \multicolumn{2}{c}{$\mathrm{mp}\left[\right.$ lit. value (Ref.)] $\left({ }^{\circ} \mathrm{C}\right)$} & $v_{\mathrm{C}=0} / \mathrm{cm}$ (acid; ester) & Yield (\%) & $\mathrm{M}_{\mathrm{r}}$ expected/found \\
\hline $\mathrm{CH}_{3} \mathrm{CO}-$ acetyl & $134-136$ & {$[135(25)]$} & $1679 ; 1749$ & 82 & $180.2 / 179.3$ \\
$\mathrm{CH}_{3} \mathrm{CH}_{2}$ CO-propanoyl & $88-91$ & {$[90-93(26)]$} & $1680 ; 1759$ & 79 & $194.2 / 196.9$ \\
$\mathrm{CH}_{3}\left(\mathrm{CH}_{2}\right)_{2}$ CO-butanoyl & $78-81$ & {$[78-79(26)]$} & $1680 ; 1754$ & 75 & $208.2 / 208.4$ \\
$\mathrm{CH}_{3}\left(\mathrm{CH}_{2}\right)_{4}$ CO-hexanoyl & $72-75$ & {$[73-75(26)]$} & $1689 ; 1768$ & 72 & $236.3 / 233.4$ \\
\hline
\end{tabular}

${ }^{a}$ Molar masses $\left(\mathrm{M}_{\mathrm{r}}\right)$ were determined by dissolving $\sim 0.5 \mathrm{~g}$ of compound (weighed to $4 \mathrm{dp}$ ) in ethanol/water and titrating with standardised $0.1 \mathrm{M} \mathrm{NaOH}$ using phenolphthalein indicator. The primary standard was potassium hydrogen phthalate. Values shown are the means of at least two separate determinations. mp, melting point; lit., literature.

\section{Materials and methods}

Chemicals and reagents. Aspirin, salicylic acid (2-hydroxybenzoic acid), MTT reagent [3-(4,5-dimethylthiazol-2-yl)-2,5diphenyltetrazolium bromide], bis(2-carboxyphenyl) succinate (BCS), 5-aminosalicylic acid (5-amino-2-hydroxybenzoic acid), vanillin (4-hydroxy-3-methoxybenzaldehyde) and DMSO (dimethyl sulfoxide) were purchased from SigmaAldrich (Dorset, UK). Dulbecco's modified Eagle's medium (DMEM) was from PAA Laboratories, and Leibovitz L-15 medium was from Sigma. All other reagents were obtained from Sigma-Aldrich unless otherwise stated. Other chemicals were synthesised in our laboratories using the methods described. As BCS availability is intermittent we offer a method for its synthesis.

Synthesis of materials. All infrared data provided were obtained on the pure solids using a Genesis II ATR FTIR spectrometer. High resolution mass spectra were obtained from the EPSRC National Mass Spectrometry Service Centre, Swansea, UK.

N,O-diacetyl-5-aminosalicylic acid (DASA) (Fig. 1Aii). 5-Aminosalicylic acid (Fig. 1Ai) (15.3 g; $0.1 \mathrm{~mol})$ was mixed with glacial acetic acid $(60 \mathrm{ml})$ and acetic anhydride $(60 \mathrm{ml})$ and refluxed for $4 \mathrm{~h}$. The hot solution was then poured onto ice/water $(400 \mathrm{ml})$ and stirred thoroughly until the precipitate was properly solidified. The mixture was then stored at $5^{\circ} \mathrm{C}$ for 12-18 $\mathrm{h}$. The resulting crude product was filtered under vacuum and re-crystallised from aqueous ethanol. The yield of white solid was $15.3 \mathrm{~g}(65 \%) ; \mathrm{mp} 192-196^{\circ} \mathrm{C}$ [lit. 196-198 ${ }^{\circ} \mathrm{C}$ (24)], m/z (CI) $255.0976\left(\mathrm{M}+\mathrm{NH}_{4}{ }^{+}, \mathrm{C}_{11} \mathrm{H}_{11} \mathrm{NO}_{5} \mathrm{NH}_{4}\right.$ requires 255.0975).

General method for synthesis of alkanoylsalicylate analogues (Fig. 1B). Salicylic acid (6 g; $0.0435 \mathrm{~mol})$ in a 100-ml conical flask was mixed with dry THF $(35 \mathrm{ml})$ and pyridine $(4 \mathrm{ml}$; $0.05 \mathrm{~mol}$ ), and the solution was then stirred until the salicylic acid had completely dissolved. The appropriate acid chloride ( $0.0435 \mathrm{~mol}$ dissolved in $10 \mathrm{ml}$ THF) was then added dropwise to the rapidly stirring mixture at a rate necessary to maintain the temperature at $35-45^{\circ} \mathrm{C}$. After complete addition, the mixture was stirred for a further 15-30 min. Ice-cold water $(40 \mathrm{ml})$ was added, and the mixture was stirred or triturated until the crude product had completely solidified. More cold water/ice was added when solidification was slow. The crude solid was filtered and re-crystallised from aqueous ethanol, aqueous methanol or ethanol/toluene to produce colourless solids in every case. In this way samples of the analogues [(Fig. 1B) $\mathrm{X}=\mathrm{i}-\mathrm{v}]$ were prepared. Yields, melting points, purity criteria $\left(\mathrm{M}_{\mathrm{r}}\right.$ by acid-base titration) and IR carbonyl stretching frequencies are provided in Table I.

Bis(2-carboxyphenyl) succinate (BCS) (Fig. 1D). Salicylic acid (27.6 g; $0.2 \mathrm{~mol}$ ) was added to a 2-neck 250-ml Quickfit round bottom flask fitted with a condenser, dropping funnel, silica gel guard tubes and magnetic stirrer. Pyridine $(16.1 \mathrm{ml} ; 0.2 \mathrm{~mol})$ was added through the dropping funnel, followed by dry THF (75 ml; dried over anhydrous magnesium sulphate for $24 \mathrm{~h}$ ). The mixture was then stirred magnetically until the salicylic acid had completely dissolved. A solution of succinyl chloride $(11.0 \mathrm{ml} ; 0.1 \mathrm{~mol})$ in dry THF $(25 \mathrm{ml})$ was then added dropwise (over 20-30 min) with vigorous stirring. A mildly exothermic reaction ensued and a precipitate was soon apparent. Additional dry THF (up to $30 \mathrm{ml}$ ) was added when the slurry became too thick to stir efficiently. The mixture was then stirred vigorously for a further $1 \mathrm{~h}$. The resulting mixture was then poured slowly into ice-cold water $(300-500 \mathrm{ml})$ which was rapidly stirred in a 1-liter conical flask. Stirring was continued (up to $1 \mathrm{~h}$ ) until the precipitated product was sufficiently crystalline to be filtered with a Buchner apparatus. More cold water was added at this stage when solidification of the product was slow. The crude yield was $29.5 \mathrm{~g}(82 \%)$. The product was re-crystallised from ethanol to produce a white solid. IR: $v_{\mathrm{C}=\mathrm{O}}$ acid $1680 / \mathrm{cm}, v_{\mathrm{C}=\mathrm{O}}$ ester $1749 / \mathrm{cm}$; mp: $169-171^{\circ} \mathrm{C}$ [lit. $160-165^{\circ} \mathrm{C}(21), 183-184^{\circ} \mathrm{C}$ (22), $\left.178-180^{\circ} \mathrm{C}(23)\right], \mathrm{m} / \mathrm{z}(\mathrm{CI}) 376.1030\left(\mathrm{M}+\mathrm{NH}_{4}{ }^{+}, \mathrm{C}_{18} \mathrm{H}_{14} \mathrm{O}_{8} \mathrm{NH}_{4}\right.$ requires 376.1027). Our material, after re-crystallisation, gave a negative phenol test with ferric chloride solution, and the IR spectrum was essentially identical to the commercial compound.

Benozylaspirin (Fig. 1E). Benzoylaspirin was prepared using the method described for the alkanoylsalicylate analogues (Fig. 1B) above, using benzoyl chloride as the appropriate acid chloride. A longer reaction time (20-24 h) was allowed before the addition of cold water. The yield of a crude white solid was $60-65 \%$. The product was re-crystallised at $60-80^{\circ} \mathrm{C}$ in petroleum ether to produce a white solid. IR: $v_{\mathrm{C}=\mathrm{O}}$ acid 1697/ $\mathrm{cm}, v_{\mathrm{C}=\mathrm{O}}$ ester $1739 / \mathrm{cm} ; \mathrm{mp}: 130-132^{\circ} \mathrm{C}$ [lit. $\left.131^{\circ} \mathrm{C}(51)\right]$.

Fumaroyldiaspirin (Fig. 1F). Fumaroyldiaspirin was prepared using the method described for bis(2-carboxyphenyl) succinate (Fig. 1D) above. Succinyl chloride was replaced with fumaroyl 
chloride, and the crude yield was $71 \%$. The product was re-crystallised by dissolving in a minimum of boiling acetone and then adding $60-80^{\circ} \mathrm{C}$ petroleum ether until the hot solution became cloudy. Cooling produced a white solid. IR: $v_{\mathrm{C}=\mathrm{O}}$ acid $1680 / \mathrm{cm}, v_{\mathrm{C}=\mathrm{O}}$ ester $1737 / \mathrm{cm}$; mp: $190-192^{\circ} \mathrm{C}$ [lit. $178-180^{\circ} \mathrm{C}$ (22)], m/z (CI) $374.0875\left(\mathrm{M}+\mathrm{NH}_{4}^{+}, \mathrm{C}_{18} \mathrm{H}_{14} \mathrm{O}_{8} \mathrm{NH}_{4}\right.$ requires 374.0870).

Cell culture. The human colorectal cancer SW480 cell line was cultured in L-15 medium containing 10\% FBS (PAA Laboratories, Somerset, UK), supplemented with L-glutaminepenicillin-streptomycin (Sigma). The U373 (astrocytoma, grade III), MCF7 and MDA-MB-231 (both breast cancer) cell lines were cultured in Dulbecco's minimal essential medium (PAA Laboratories) with 10\% FBS and L-glutamine-penicillinstreptomycin. Cells were cultured at $37^{\circ} \mathrm{C}$ in a humidified incubator with $5 \% \mathrm{CO}_{2}$ (apart from the $\mathrm{SW} 480$ cells, cultured without $\mathrm{CO}_{2}$ ) and regularly passaged at $\sim 80 \%$ confluency. Cell lines were purchased from the European Collection of Cell Cultures (Porton Down, UK).

Cell viability assay. Compounds were prepared as a stock $(0.5 \mathrm{M})$ in DMSO, prior to addition to the cells. Cell viability was measured using the MTT assay (27) with modifications (28). Briefly, $10^{4}$ cells/well were cultured overnight, and the medium was discarded and replaced with medium containing the drugs at the required concentration and incubated for $24 \mathrm{~h}$. The medium was then replaced with $300 \mu \mathrm{l}$ of (MTT) stain per well, incubated for $3 \mathrm{~h}$, and $200 \mu \mathrm{l}$ of DMSO was added. Incubation was carried out for $10 \mathrm{~min}$ at $37^{\circ} \mathrm{C}$, and the absorbance was recorded at $540 \mathrm{~nm}$ using a visible plate reader (Labsystems Multiskan MS). Viability was reported as the percentage of treated cells relative to the cells in the control wells. The values are expressed as the mean from three independent experiments; and unless stated, bars in the figures indicate $\pm \mathrm{SD}$.

Evaluation of Apo-TRACE accumulation in apoptotic cells. The apoptotic potential of the compounds was tested in vitro using the commercially available Apo-TRACE ${ }^{\mathrm{TM}}$ Apoptotic Cell Staining Kit (Sigma-Aldrich), which utilises a small non-toxic compound of the ApoSense family of compounds, according to the manufacturer's instructions (29). Briefly, at $80-90 \%$ confluency, SW480 cells were incubated with either $1 \mathrm{mM}$ aspirin, $0.5 \mathrm{mM}$ BCS, carrier amounts of DMSO or $25 \mu \mathrm{M}$ irinotecan for 24 or $48 \mathrm{~h}$, and the medium containing the drug was removed. The cells were washed and incubated for $30 \mathrm{~min}$ in the dark, then washed with PBS, and stained with $250 \mu \mathrm{l} /$ well of working medium B [75 $\mu \mathrm{g} / \mathrm{ml}$ of Apo-TRACE and $0.5 \mu \mathrm{g} / \mathrm{ml}$ of propidium iodide (PI)]. Cells were incubated for $30 \mathrm{~min}$ in the dark, and washed with PBS and placed onto a drop of VectaShield ${ }^{\circledR}$ mounting medium (Vector Laboratories Inc.), prior to immediate epifluorescence microscopy.

Epifluorescence microscopy. Cells were visualised using an Olympus fluorescence microscope (BX61; Olympus Optical, UK), with UV illumination from a mercury lamp. Apo-TRACE and PI staining were visualised with DAPI (excitation $350 \mathrm{~nm}$; emission $470 \mathrm{~nm}$ ) and Texas Red (excitation $596 \mathrm{~nm}$; emission $615 \mathrm{~nm}$ ) filter sets, respectively. The accumulation of Apo-TRACE in the cytoplasm of cells is a feature of apoptosis while nuclear
PI (red fluorescence) staining is indicative of non-viable cells and can reflect necrosis or secondary necrosis that results as a consequence of apoptosis.

Quantitation of apoptosis. Apoptosis was measured using an ELISA-based HT TiterTACS Assay Kit (Trevigen, Gaithersburg, MD, USA), which detects DNA fragmentation. At $48 \mathrm{~h}$, cells were centrifuged, briefly washed in 1X PBS and fixed in $3.7 \%$ $(\mathrm{w} / \mathrm{v})$ buffered formaldehyde solution for $7 \mathrm{~min}$. Cells were then washed with 1X PBS and post-fixed in $100 \%$ (v/v) methanol for $20 \mathrm{~min}$. Following the manufacturer's instructions, the cells were permeabilised with Cytocin and incubated for 30 min, washed with $\mathrm{dH}_{2} \mathrm{O}$ and positive controls generated using TACS-nuclease incubated at $37^{\circ} \mathrm{C}$ for $30 \mathrm{~min}$. Cells were then quenched with $3 \%(\mathrm{v} / \mathrm{v}) \mathrm{H}_{2} \mathrm{O}_{2}$ solution (92\% methanol, $8 \% \mathrm{H}_{2} \mathrm{O}_{2}$ ) and briefly incubated in $1 \mathrm{X}$ TdT labelling buffer. Cells were then incubated with the labelling reaction mix [1X TdT labelling buffer, TdT dNTP mix, $\mathrm{Mn}^{2+}$, TdT enzyme (enzyme omitted for control samples)] for $1 \mathrm{~h}$ to label breaks in DNA. Strep-HRP was added to each well and incubated for $10 \mathrm{~min}$ before washing with $0.1 \%(\mathrm{v} / \mathrm{v})$ Tween-20 in PBS. TACS-Sapphire was then added to the wells to detect apoptotic cells. The reaction was stopped with $2 \mathrm{~N} \mathrm{HCl}$ after $30 \mathrm{~min}$ of incubation in the dark, and the absorbance was read at $450 \mathrm{~nm}$ using a Multiskan Ascent plate reader. The unlabelled controls were suggested by the manufacturer and were samples in which the TdT enzyme was omitted from the labelling reaction mix; that is, to measure any non-specific binding of the Strep-HRP. The negative control was cells treated with only equivalent amounts of carrier molecule (DMSO).

Statistical analyses. Statistical differences were assessed by ANOVA or the Student's t-test. For each test, $\mathrm{P}<0.05$ was considered statistically significant.

\section{Results}

Previously, it has been observed that only relatively minor changes can be made to the structure of aspirin without a significant loss of activity as demonstrated in a range of studies related to the measures of aspirin activity such as inhibition of oxidative phosphorylation or platelet aggregation $(30,31)$. Similarly the positional isomers of salicylic acid, namely 3-hydroxy and 4-hydroxy benzoic acid, have also been shown to be inactive against rheumatic fever and animal inflammation. While these observations are suggestive of a need to preserve the ortho- relationship between the carboxylic acid (or substitute function) and the phenolic - $\mathrm{OH}$ group or acetoxy group, the situation is not particularly clear because of the many targets that aspirin appears to affect and the likelihood that precise structure-activity relationships will be target-dependent. We therefore attempted to clarify which structural aspects are important for preservation or enhancement of cell killing properties. In doing this we investigated the effect of the alkanoyl chain length in the phenolic ester moiety of aspirin and also the effect of replacing part of the alkanoyl chain with another aspirin moiety. The compounds utilised in this study are illustrated in Fig. 1 and were purchased and/or synthesised as indicated in Materials and methods. Properties of the alkanoyl salicylates prepared are provided in Table I. 
A

i) $\mathrm{R}=\mathrm{R}^{\prime}=\mathrm{H}$.

ii) $\mathrm{R}=\mathrm{R}^{\prime}=\mathrm{CH}_{3} \mathrm{CO}$ -<smiles>[R]Nc1ccc([R])c(C(=O)O)c1</smiles>

B<smiles>[X]Oc1ccccc1C(=O)O</smiles>

$\mathrm{X}=$ i) $\mathrm{H}$-, ii) $\mathrm{CH}_{3} \mathrm{CO}$-, iii) $\mathrm{CH}_{3} \mathrm{CH}_{2} \mathrm{CO}$-, iv) $\mathrm{CH}_{3}\left(\mathrm{CH}_{2}\right)_{2} \mathrm{CO}-$, v) $\mathrm{CH}_{3}\left(\mathrm{CH}_{2}\right)_{4} \mathrm{CO}$ -<smiles>COc1cc(C=O)ccc1O</smiles><smiles>O=C(CCC(=O)Oc1ccccc1C(=O)O)Oc1ccccc1C(=O)O</smiles>

E<smiles>O=C(Oc1ccccc1C(=O)O)c1ccccc1</smiles>

$F$<smiles>O=C(/C=C/C(=O)Oc1ccccc1C(=O)O)Oc1ccccc1C(=O)O</smiles>

Figure 1. Structures of compounds examined in this study. (A) Aspirin and salicylic acid variants at the 5-position. (B) Aspirin variants with variable alkanoyl chain length. (C) Vanillin (4-hydroxy-3-methoxybenzaldehyde). (D) Bis(2-carboxyphenyl) succinate (BCS; PN508). (E) Benzoylaspirin (Benzosalin, PN514). (F) Fumaroyldiaspirin (PN517).

The toxicity of salicylic acid (SA) derivatives was examined in a preliminary screening using the SW480 colorectal cancer cell line (Fig. 2); for clarity we indicated the effect of drugs at a concentration of $1 \mathrm{mM}$. A commercially available derivative of SA at the 5-position, 5-ASA (mesalazine), was tested as it is a well-tolerated drug with no gastrointestinal toxicity and is used in the treatment of inflammatory bowel disease. The regular use of 5-ASA is also strongly protective against CRC

development (32) and has been reported to improve replication fidelity in cultured (HCT116) colorectal cells (33). 5-ASA was found to exhibit similar toxicity to aspirin at lower concentrations $(0.5-1 \mathrm{mM})$ but at higher concentrations $(>1 \mathrm{mM})$, was noticeably less cytotoxic than aspirin in the assay system employed (Fig. 2A) (data not shown). 5-ASA was then modified by diacetylation to produce N,O-diacetyl-5-aminosalicylic acid (DASA) in an attempt to enhance cytotoxicity, but this was found to little alter the toxicity vs. the parent compound (Fig. 2A). It is worth noting that salicylate concentrations in the low $\mathrm{mM}$ range are achievable physiologically with prescribed doses of aspirin (34).

Vanillin (4-hydroxy-3-methoxybenzaldehyde) (Fig. 1C), a naturally occurring compound found in the pods of Vanilla spp, was found to significantly alter gene expression in the HepG2 human hepatocellular carcinoma cell line (35) and suppress the invasion and migration of mammary adenocarcinoma cancer cells (36). Vanillin also has anti-mutagenic properties against spontaneous mutations in mammalian cells (37) and although clearly does not possess the same functionality as aspirin, it does have ortho-disposed hydrogen bond acceptor and donor groups as well as the aldehyde carbonyl in lieu of the carboxyl one. Vanillin exhibited weak toxicity against the SW480 cell line as assessed in the MTT assay (Fig. 2A). Intriguingly, bis(2-carboxyphenyl) succinate (BCS) (see Materials and methods for the synthesis protocol) was noted to be significantly more cytotoxic than ASA, vanillin, 5-ASA and the DASA derivative. Similar results (Fig. 2A) were observed for commercially available BCS (Sigma-Aldrich) and for in-house synthesised BCS. By interpolation, for experiments with a $24-\mathrm{h}$ incubation, the $\mathrm{IC}_{50}$ of aspirin was determined as $\sim 1.0 \mathrm{mM}$, while that of BCS was $<0.5 \mathrm{mM}$ in SW480 cells. By comparison vanillin had an $\mathrm{IC}_{50}$ value of $\sim 2.5 \mathrm{mM}$ (data not shown). This is in concordance with a recent study investigating the toxicity of vanillin to the HT-29 human CRC cell line, where vanillin had a reported $\mathrm{IC}_{50}$ of

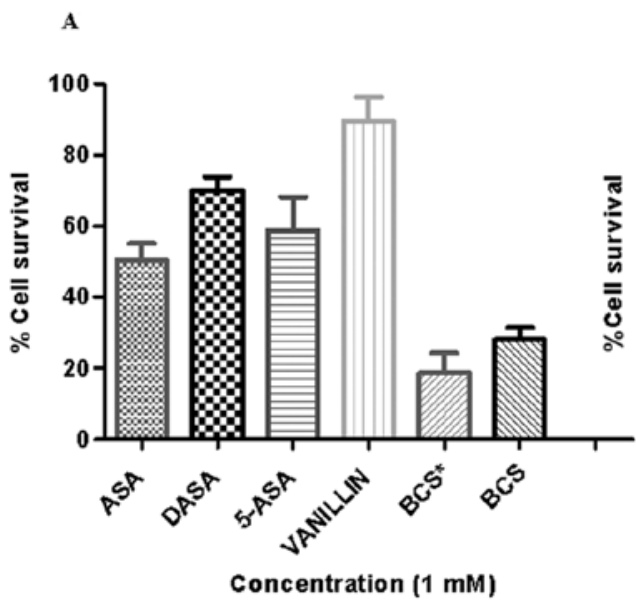

B

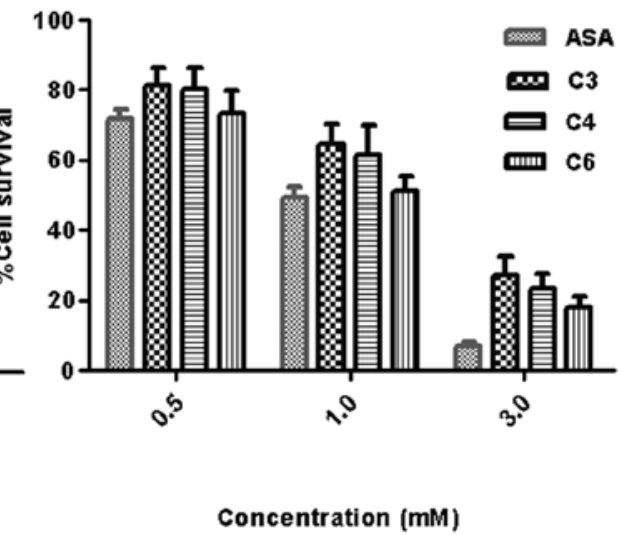

Figure 2. Salicylic acid derivatives and vanillin were tested for their toxicity to the SW480 colorectal cancer cell line. (A) Cells were plated at a density of $10^{4}$ cells/well in 96-well microtitre plates. Twenty-four hours after seeding, the cells were treated with the compound-containing culture medium for $24 \mathrm{~h}$. The anti-proliferative effects were measured by the MTT assay. All compounds were dissolved in DMSO. ASA, acetylsalicylic acid; DASA, N,O-diacetyl-5aminosalicylic acid; 5-ASA, 5-aminosalicylic acid; Vanillin, 4-hydroxy-3-methoxybenzaldehyde; BCS*, the commercially available form of bis(2-carboxyphenyl) succinate (Fig. 1D). BCS was synthesised in-house according to the protocol described herein. Bis(2-carboxyphenyl) succinate consistently exhibited greater toxicity to the cell line than related compounds. Mean \pm SD. (B) Cells were treated similarly with medium containing salicylates with modified alkanoyl chain lengths, either C3, C4 or C6 (see structures in Fig. 1B). The toxicity of ASA is shown for comparison. Mean \pm SEM. 


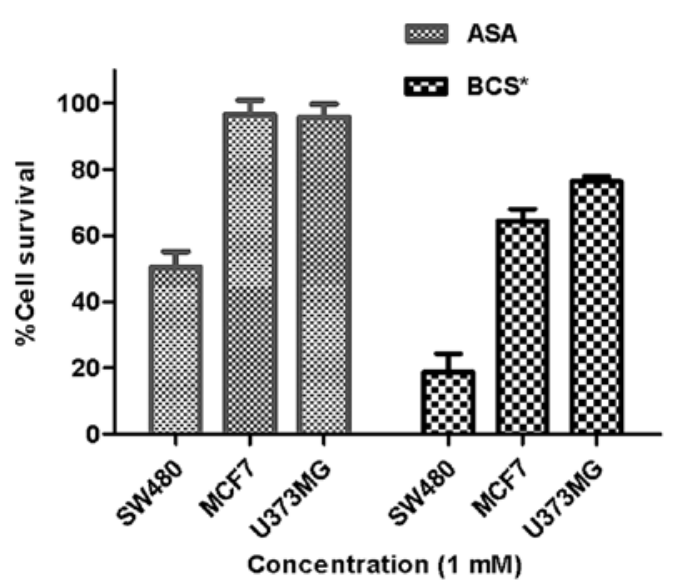

Figure 3. The effect of ASA and BCS on the cell viability of colorectal and non-colorectal human cancer cell lines. Each cell line was plated at a density of $10^{4}$ cells/well in 96-well microtitre plates. Twenty-four hours after seeding, the cells were treated with culture medium with or without ASA or BCS" (Sigma-Aldrich) for $24 \mathrm{~h}$. The anti-proliferative effects were measured by the MTT assay. BCS ${ }^{*}$, the commercially available form of bis(2-carboxy-phenyl) succinate.

$2.6 \mathrm{mM}$ (38). For clarity we should state that SA is recognised as the principal metabolite of aspirin (39). Salicylic acid per se exhibited similar toxicity to ASA against the SW480 CRC cell line in the concentration range of 0.5-1 $\mathrm{mM}$ (data not shown).

We then examined whether further extension of the acetyl group - with a C3, C4 and C6 chain - significantly enhanced the toxicity of salicylic acid in comparison to aspirin. Marginally less toxicity than ASA was noted, indicating that further extending the alkanoylsalicylate (Figs. 1 and 2B) chain length does not appear to enhance the inhibitory effect of the parent compound. The effect on cell viability of aspirin and these chain-extended salicylates in the SW480 cells was not apparent in a cell line derived from a brain tumour (U373 MG), even over extended (up to $72 \mathrm{~h}$ ) time periods (data not shown). This indicates a specific sensitivity of colorectal cancer cells to NSAID-'like' molecules. In addition, BCS - like ASA - while notably toxic to the SW480 cells, exhibited substantially less toxicity in the human MCF7 breast cancer and U373 glioma cell line at a concentration of $1 \mathrm{mM}$ (Fig. 3). The sensitivity of cultured cells to NSAIDs was previously examined by Din et al in some detail, who reported that a 'considerable degree of cell type specificity' of ASA was noted in colorectal cancer cells vs. cells derived from breast, ovarian and endometrial cancers (20, and references therein). Consequently, we tested the toxicity of BCS in greater detail and controlled for any toxicity associated with the carrier molecule (Fig. 4) by testing for a dose-dependent decrease in cell viability. We observed that the DNA mismatch repair incompetent HCT116 CRC cell line was marginally less sensitive to BCS than the SW480 cell line. A similar finding was previously reported with respect to the response of these lines to ASA - with $\mathrm{IC}_{50}$ values of 1.48 and $2.71 \mathrm{mM}$ - for SW480 and HCT116 cells, respectively (20). By contrast, the breast cancer cell line MDA-MB-231 was found, even at relatively high concentrations, to be relatively resistant to the growth inhibitory effects of BCS (Fig. 4C). This evidence confirms that CRC cell lines are sensitive to ASA-based compounds, and may suggest that the presence of
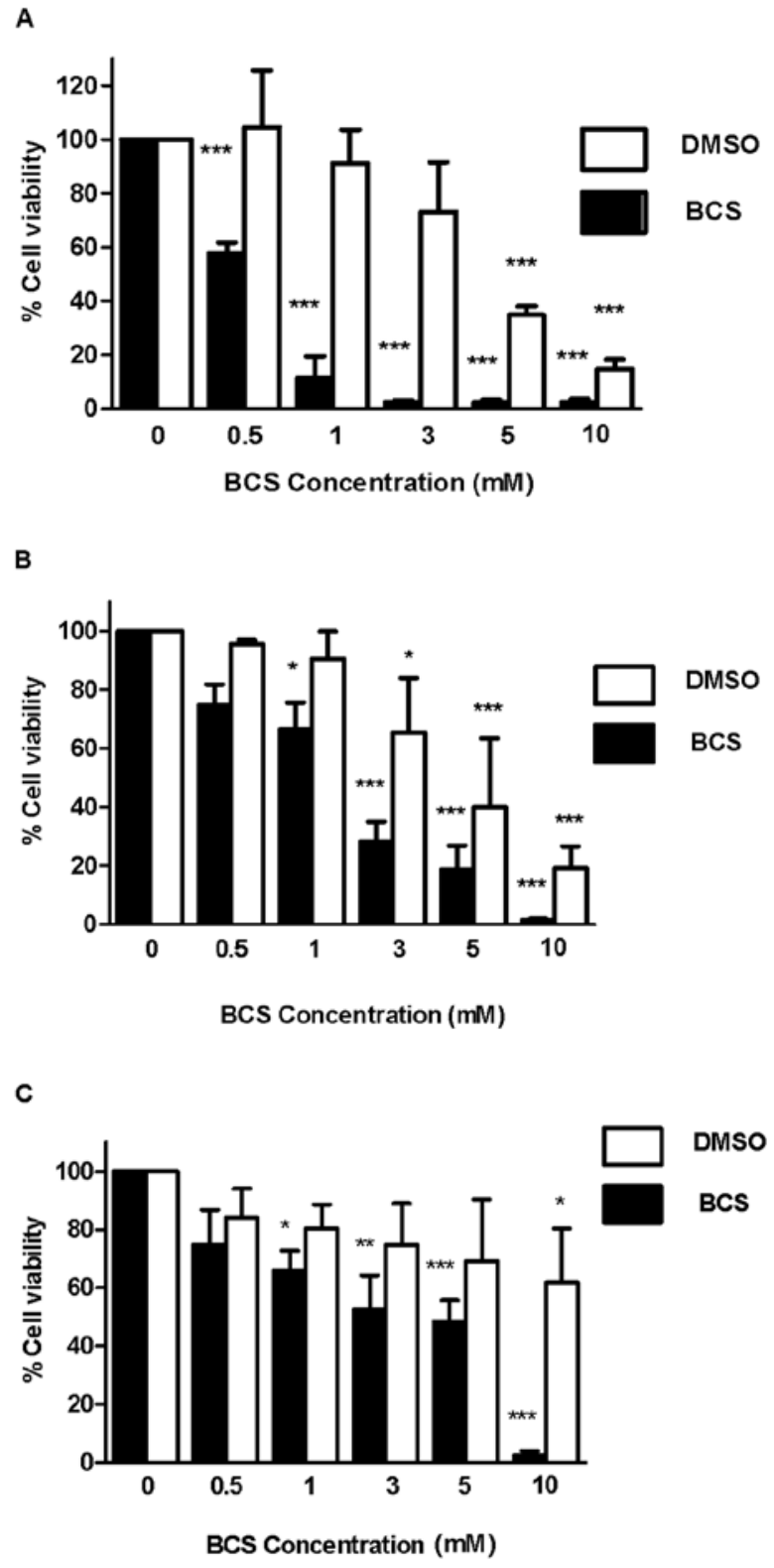

Figure 4. Dose-response effect of in-house synthesised bis(2-carboxyphenyl) succinate (BCS) on the viability of SW480 (A) and HCT116 (B) human colon cancer cells and MDA-MB-231 breast cancer cells (C). Each cell line was plated at a density of $10^{4}$ cells per well in 96-well microtitre plates. Twentyfour hours after seeding, the cells were treated with compound-containing culture medium for $24 \mathrm{~h}$. The anti-proliferative effects were measured by the MTT assay. Note that the amount of DMSO added to check for carrier toxicity itself was equal to that for DMSO for each relevant concentration of the compound. ${ }^{*} \mathrm{P}<0.5,{ }^{* *} \mathrm{P}<0.05,{ }^{* * *} \mathrm{P}<0.005$ (one-way ANOVA with Tukey's multiple comparison test). Viability is relative to the controls with no drug added to the medium and we included $100 \%$ viability at $0 \mathrm{mM}$ of the drug added for clarity.

a second nearby aromatic ring is beneficial to a binding relationship in the cytotoxicity of salicylates. To pursue this line of inquiry further, benzoylaspirin and fumaroyldiaspirin were synthesised (Fig. 1, Materials and methods), and their toxicity to the SW80 cell line was analysed. These compounds exhibited substantially greater toxicity than aspirin (Fig. 5).

We examined whether the cell death/inhibition of proliferation induced by BCS occurred via the initiation of a necrotic 


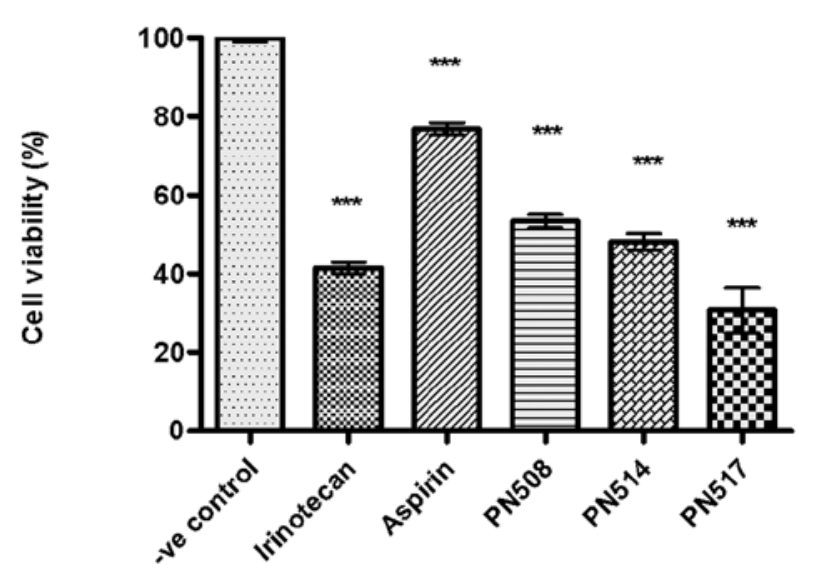

Figure 5. The effect of benzoylaspirin and fumaroyldiaspirin on the viability of the SW480 colorectal cancer cell line. Each cell line was plated at a density of $10^{4}$ cells/well in 96 -well microtitre plates. Twenty-four hours after seeding, the cells were treated with culture medium with or without the compounds indicated at $0.5 \mathrm{mM}$ for $48 \mathrm{~h}$. The anti-proliferative effects were measured by the MTT assay. The response to irinotecan (incubated at $25 \mu \mathrm{M})$ is included for comparison. Benzoylaspirin is denoted as PN514 and fumaroyldiaspirin as PN517. Results are plotted as the average of three separate experiments, with each bar representing experiments performed in triplicate \pm SEM $\left({ }^{* * * *} \mathrm{P}<0.005\right.$; one-way ANOVA with Tukey's multiple comparison test).

or apoptotic pathway. In this regard, previous findings have been rather contradictory for aspirin: in vitro studies have suggested that while ASA inhibits CRC proliferation, this may, $(20,40)$ or may not $(7,41)$, occur through induction of apoptosis, or may occur as a consequence of the combination of both pathways (16). We utilised a commercially available apoptotic cell staining kit (Apo-TRACE) that responds to phospholipid scrambling, a canonical feature of the apoptotic pathway. The Apo-Trace compound accumulates in the cytoplasm of apoptotic cells. End-stage apoptosis and death is characterised by cells accumulating the Apo-Trace compound (N,N'-didansylL-cystine) (29) and staining positively for PI. PI binds to double-stranded DNA and can only permeate a compromised plasma membrane thus staining only non-viable cells. The DNA topoisomerase inhibitor irinotecan clearly promoted a significant uptake of the Apo-Trace compound, as expected for a drug associated with growth inhibition and apoptotic induction (Fig. 6A) $(42,43)$. In contrast, much less uptake of the compound was noted with ASA or BCS (Fig. 6B and C), suggesting that these salicylates activated the necrotic pathway in the cell line tested. However, staining also suggestive of apoptosis was consistently noted with both compounds (Fig. 6). The carrier molecule (DMSO) used to dissolve the compounds tested in this study did not induce cell death. To further characterise the degree of apoptosis, semi-quantitative analysis (Trevigen HT TiterTACS assay kit) confirmed the presence of apoptotic cells in the treated cultures (Fig. 7), and indicated that compounds containing two ring structures appeared to induce a greater degree of apoptosis than the parent drug ASA, under the conditions tested.

\section{Discussion}

Salicylates may be found as constituents of a normal diet (fruit and vegetables) and, notwithstanding our ignorance of the molecular pathways they activate in the gut epithelium, one can reasonably infer that ingestion of such dietary salicylates may contribute to the health of an individual by reducing colorectal cancer incidence $(39,44)$. In an effort to understand the molecular basis of the growth inhibitory effect of ASA against cancer cells we examined a number of derivatives of
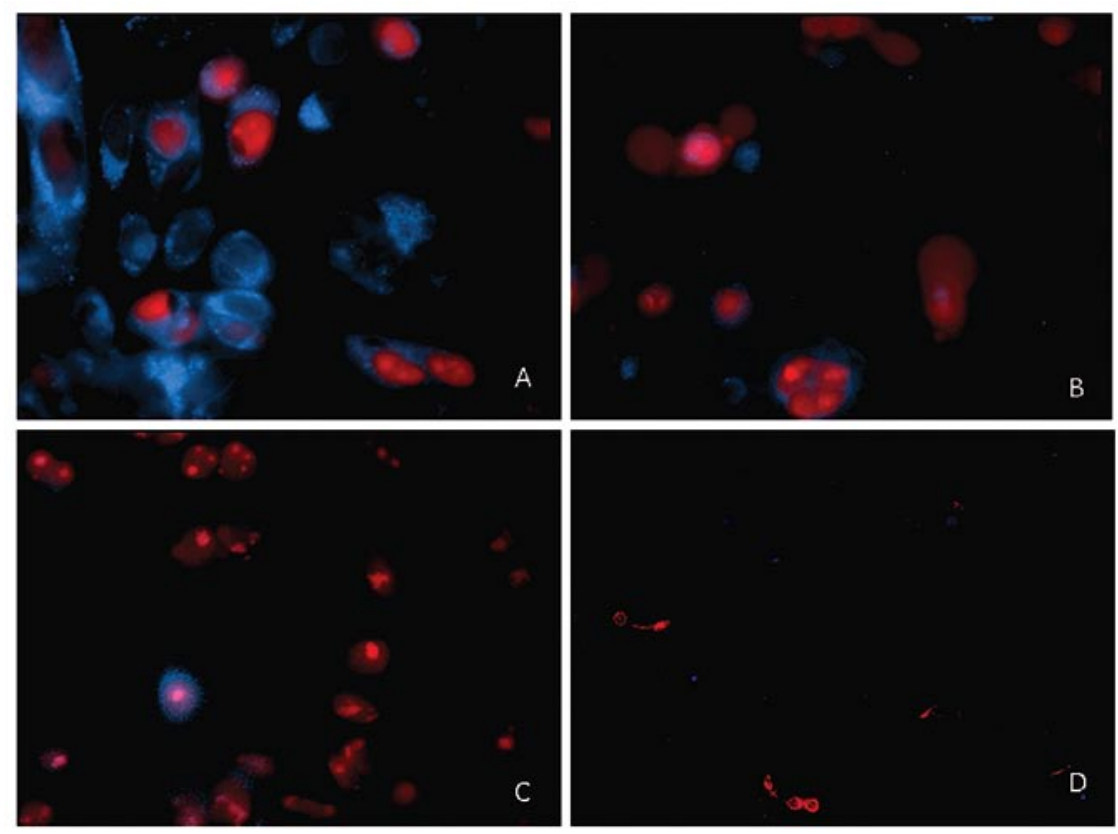

Figure 6. Fluorescence imaging of cells incubated with cytotoxic compounds and stained with the Apo-TRACE cell staining kit. The colorectal cancer SW480 cell line was incubated for $24 \mathrm{~h}$ with either $25 \mu \mathrm{M}$ irinotecan (A), $1 \mathrm{mM}$ ASA (B), $0.5 \mathrm{mM}$ BCS (C) or the carrier molecule DMSO (D). Blue staining, ApoTrace; propidium iodide counterstaining, red. Magnification x400. 


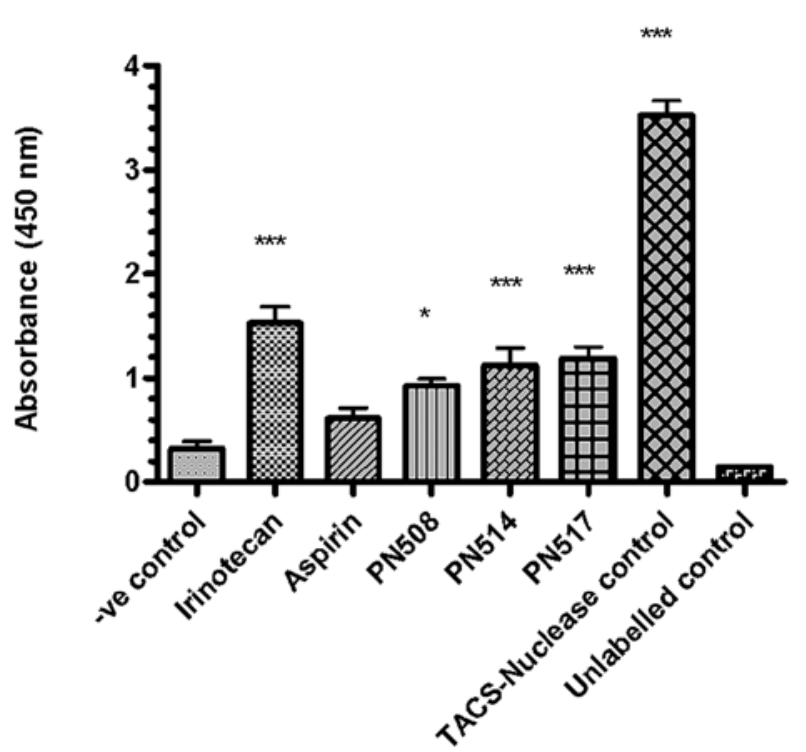

Figure 7. Quantitative analysis of apoptosis induction by aspirin analogues in the SW480 colorectal cancer cell line. The SW480 cell line was incubated with $0.5 \mathrm{mM}$ aspirin, PN508 (BCS), PN514 (benzoylaspirin), PN517 (fumaroyldiaspirin) or $25 \mu \mathrm{M}$ irinotecan for $48 \mathrm{~h}$ and apoptosis was quantified employing the Trevigen HT TiterTACS assay kit. Each bar represents \pm SEM from three experiments performed in triplicate. Statistical analysis indicated a significant increase $\left({ }^{* * *} \mathrm{P}<0.005\right.$; one-way ANOVA with Tukey's multiple comparison test) in treated cells compared to untreated cells.

salicylic acid. While this study did not directly provide evidence to elucidate the mechanism through which toxicity occurs, we identified a candidate molecule, BCS, which was markedly more toxic than ASA yet retains a degree of specificity towards cells derived from colorectal cancers and thus may prove useful to the study of this phenomenon (Fig. 2). Why CRCs show a remarked sensitivity to these molecules is unclear: however, it may potentially be an 'Achilles heel' and to that end, worth pursuing further. Numerous molecular pathways have been reported to be important with regard to the toxicity of aspirin to colorectal cancer cells. For example, it has been suggested that ASA up-regulates NF- $\kappa$ B expression specifically in colorectal cells and this has been correlated with apoptosis (20). However, other researchers have reported that ASA inhibits NF- $\kappa \mathrm{B}$ expression (11), and indeed NF- $\kappa \mathrm{B}$ mediated suppression of GADD $45 \alpha$ and GADD $45 \gamma$ genes in non-colorectal cancer cell lines has been found to be essential for cancer cell survival (45).

In our opinion, the numerous pathways invoked for the effect of ASA highlight our ignorance of the metabolic management (which may be unique) by colorectal cells of salicylates. What is clear is that ASA has pleiotropic effects and can affect the cell cycle, cell proliferation, differentiation and cell death. Further confounding our understanding of NSAID toxicity is the apparently contradictory reports in the literature of the cell death pathway activated by NSAIDs. Subbegowda and Frommel reported that ASA did not induce apoptosis in SW620 and HT-29 colorectal cancer cells as assessed by Annexin V and PI staining utilising flow cytometry (46), while Chan et al found that NSAIDs (sulindac sulfide and indomethacin) induced apoptosis in HCT116 and SW480 cells at a low concentrations and exhibited non-specific toxic effects at higher concentration (47). The induction of apoptosis was determined by examination of nuclear condensation and fragmentation, and exposure of phosphatidylserine groups on the surface and Chan et al also proposed that apoptosis occurs as a consequence of elevated arachidonic acid and ceramide levels. In the present study (low concentrations of) ASA and BCS largely exerted their toxicity via the necrotic pathway (Fig. 6), although we did observe relatively low levels (in comparison to exposure to irinotecan) of Apo-TRACE compound-staining consistent with the activation of an apoptotic pathway in SW480 cells. Quantitative analysis also confirmed that apoptosis occurs in cells exposed to aspirin and its derivatives, although the levels are somewhat modest when compared to an induction by irinotecan. It is possible that activation of apoptosis in a subset of cells may reflect a sensitivity that is related to a specific stage of the cell cycle. As the molecular basis of the toxicity of aspirin to CRC is unclear, it is premature to speculate on the action of BCS and PN514 (benzoylaspirin) and PN517 (fumaroyldiaspirin). However, we question, based on the pleiotropic nature of pathways altered in cells exposed to NSAIDs whether BCS and other derivatives (or indeed the 'monomeric' version, aspirin) can alter the epigenetic status of cells by perturbing either the histone deacetylases or DNA methyltransferases thus altering transcription globally and 'tipping' the cells towards a necrotic or apoptotic pathway. We also suggest that the anti-inflammatory capacity of BCS, PN514 and PN517 should be determined and speculate that the biological activities of these analogues with two aromatic rings may in principle be useful towards the understanding of the molecular basis for the toxicity of saliclylate-based compounds in colorectal cancer cells.

With respect to the synthesis of novel anticancer drugs based on salicylates, nitric oxide (NO)-releasing derivatives of NSAIDs such as NCX4040 [2-(acetyloxy)benzoic acid 4-(nitrooxymethyl)phenyl ester] have been reported to be significantly (2500- to 5000-fold) more potent in suppressing colon cancer cell growth and in inhibiting $\mathrm{NF}-\kappa \mathrm{B}$ and the $\beta$-catenin/T-cell factor signalling pathway in comparison to 'traditional' ASA $(48,49)$. NCX 4040 has recently been reported to have enhanced antitumour efficacy vs. aspirin and acts as a sensitising agent for the alkylating agent oxaliplatin, which is currently in use as a therapeutic agent for colorectal cancer (50). We suggest that modifying BCS may result in novel compounds that are significantly and specifically more toxic than BCS itself to colorectal cancer, and our laboratory is vigorously pursuing this avenue of research. It is also conceivable that BCS (and its derivatives) may have the capacity to sensitise colorectal cancer cells to current and novel anti-colorectal cancer chemotherapeutic agents, and to that end we provide a simple method for the synthesis of BCS to facilitate the investigation of this hypothesis.

\section{Acknowledgements}

This study was supported by the Research Institute in Healthcare Science at the University of Wolverhampton. We wish to thank Keith Holding and Dr Malcolm Inman for technical support. We are grateful to Dr Paul Hooley for reviewing the manuscript. 


\section{References}

1. Baron JA, Cole BF, Sandler RS, et al: A randomized trial of aspirin to prevent colorectal adenomas. N Engl J Med 348: 891-899, 2003.

2. Imperiale TF: Aspirin and the prevention of colorectal cancer. N Engl J Med 348: 879-880, 2003.

3. Sandler RS, Halabi S, Baron JA, et al: A randomized trial of aspirin to prevent colorectal adenomas in patients with previous colorectal cancer. N Engl J Med 348: 883-890, 2003.

4. Sansom OJ, Stark LA, Dunlop MG and Clarke AR: Suppression of intestinal and mammary neoplasia by lifetime administration of aspirin in Apc(Min/+) and Apc(Min/+), Msh2(-/-) mice. Cancer Res 61: 7060-7064, 2001.

5. Thun MJ, Henley SJ and Patrono C: Non-steroidal antiinflammatory drugs as anticancer agents: mechanistic, pharmacologic, and clinical issues. J Natl Cancer Inst 94: 252-266, 2002

6. Strul $\mathrm{H}$ and Arber N: Non-steroidal anti-inflammatory drugs and selective apoptotic anti-neoplastic drugs in the prevention of colorectal cancer: the role of super aspirins. Isr Med Assoc J 2 : 695-702, 2000.

7. Smith ML, Hawcroft G and Hull MA: The effect of non-steroidal anti-inflammatory drugs on human colorectal cancer cells: evidence of different mechanisms of action. Eur J Cancer 36 : 664-674, 2000

8. McIlhatton MA, Tyler J, Burkholder S, et al: Nitric oxidedonating aspirin derivatives suppress microsatellite instability in mismatch repair-deficient and hereditary non-polyposis colorectal cancer cells. Cancer Res 67: 10966-10975, 2007.

9. Watson AJ: An overview of apoptosis and the prevention of colorectal cancer. Crit Rev Oncol Hematol 57: 107-121, 2006.

10. Ferrandez A, Prescott S and Burt RW: COX-2 and colorectal cancer. Curr Pharm Des 9: 2229-2251, 2003.

11. Kopp E and Ghosh S: Inhibition of NF-kappa B by sodium salicylate and aspirin. Science 265: 956-959, 1994.

12. Yin MJ, Yamamoto Y and Gaynor RB: The anti-inflammatory agents aspirin and salicylate inhibit the activity of I(kappa)B kinase-beta. Nature 396: 77-80, 1998.

13. Stark LA, Din FV, Zwacka RM and Dunlop MG: Aspirininduced activation of the NF-kappaB signaling pathway: a novel mechanism for aspirin-mediated apoptosis in colon cancer cells. FASEB J 15: 1273-1275, 2001

14. Ruschoff J, Wallinger S, Dietmaier W, et al: Aspirin suppresses the mutator phenotype associated with hereditary non-polyposis colorectal cancer by genetic selection. Proc Natl Acad Sci USA 95: 11301-11306, 1998.

15. Kim KM, Song JJ, An JY, Kwon YT and Lee YJ: Pretreatment of acetylsalicylic acid promotes tumor necrosis factor-related apoptosis-inducing ligand-induced apoptosis by down-regulating BCL-2 gene expression. J Biol Chem 280: 41047-41056, 2005.

16. Lai MY, Huang JA, Liang ZH, Jiang HX and Tang GD: Mechanisms underlying aspirin-mediated growth inhibition and apoptosis induction of cyclooxygenase-2 negative colon cancer cell line SW480. World J Gastroenterol 14: 4227-4233, 2008

17. Dibra HK, Brown JE, Hooley P and Nicholl ID: Aspirin and alterations in DNA repair proteins in the SW480 colorectal cancer cell line. Oncol Rep 24: 37-46, 2010.

18. Bos CL, Kodach LL, van den Brink GR, et al: Effect of aspirin on the Wnt/beta-catenin pathway is mediated via protein phosphatase 2A. Oncogene 25: 6447-6456, 2006.

19. Goel A, Chang DK, Ricciardiello L, Gasche C and Boland CR A novel mechanism for aspirin-mediated growth inhibition of human colon cancer cells. Clin Cancer Res 9: 383-390, 2003.

20. Din FV, Dunlop MG and Stark LA: Evidence for colorectal cancer cell specificity of aspirin effects on NF kappa B signalling and apoptosis. Br J Cancer 91: 381-388, 2004.

21. http://www.sigmaaldrich.com/catalog/productdetail.do?lang= en $\& N 4=494054$ laldrich $\& N 5=$ search_concat_PNOlbrand key\& $\mathrm{F}=$ spec

22. Zaugg RH, Walder JA, Walder RY, Steele JM and Klotz IM: Modification of hemoglobin with analogs of aspirin. J Biol Chem 255: 2816-2821, 1980 .

23. Berendes R and Callsen J: US Patent 874, 929, 1907.

24. Jorgensen AP and Menne T: Aminosalicylic-acid derivatives for the treatment of psoriasis. European Patent Application EP0291159, 1988

25. Weast RC (ed): Handbook of Chemistry and Physics. 58th edition. CRC Press, Cleveland, OH, 1977-1978.
26. Hung DY, Mellick GD, Prankerd RJ and Roberts MS: Synthesis, identification, characterization, stability, solubility and protein binding of ester derivatives of salicylic acid and diflunisal. Int J Pharm 153: 25-39, 1997.

27. Mosmann T: Rapid colorimetric assay for cellular growth and survival: application to proliferation and cytotoxicity assays. J Immunol Methods 65: 55-63, 1983.

28. Carmichael J, DeGraff WG, Gazdar AF, Minna JD and Mitchell JB: Evaluation of a tetrazolium-based semiautomated colorimetric assay: assessment of chemosensitivity testing. Cancer Res 47: 936-942, 1987.

29. Damianovich M, Ziv I, Heyman SN, et al: ApoSense: a novel technology for functional molecular imaging of cell death in models of acute renal tubular necrosis. Eur J Nucl Med Mol Imaging 33: 281-291, 2006.

30. Killackey JJ, Killackey BA and Philp RB: Structure-activity studies of aspirin and related compounds on platelet aggregation, arachidonic acid metabolism in platelets and artery, and arterial prostacyclin activity. Prostaglandins Leukot Med 9: 9-23, 1982

31. Dupin JP, Gravier D, Casadebaig F, Boisseau MR and Bernard H: Relationship between structure and activity of aspirin-related compounds on the inhibition of in vitro platelet aggregation. Farmaco Sci 41: 205-214, 1986

32. Cheng Y and Desreumaux P: 5-Aminosalicylic acid is an attractive candidate agent for chemoprevention of colon cancer in patients with inflammatory bowel disease. World J Gastroenterol 11: 309-314, 2005

33. Gasche C, Goel A, Natarajan L and Boland CR: Mesalazine improves replication fidelity in cultured colorectal cells. Cancer Res 65: 3993-3997, 2005.

34. Stark LA, Reid K, Sansom OJ, et al: Aspirin activates the NF-kappaB signalling pathway and induces apoptosis in intestinal neoplasia in two in vivo models of human colorectal cancer. Carcinogenesis 28: 968-976, 2007

35. Cheng WY, Hsiang CY, Bau DT, et al: Microarray analysis of vanillin-regulated gene expression profile in human hepatocarcinoma cells. Pharmacol Res 56: 474-482, 2007.

36. Lirdprapamongkol K, Sakurai H, Kawasaki N, et al: Vanillin suppresses in vitro invasion and in vivo metastasis of mouse breast cancer cells. Eur J Pharm Sci 25: 57-65, 2005.

37. King AA, Shaughnessy DT, Mure K, et al: Antimutagenicity of cinnamaldehyde and vanillin in human cells: global gene expression and possible role of DNA damage and repair. Mutat Res 616: 60-69, 2007.

38. Ho K, Yazan LS, Ismail N and Ismail M: Apoptosis and cell cycle arrest of human colorectal cancer cell line HT-29 induced by vanillin. Cancer Epidemiol 33: 155-160, 2009.

39. Paterson JR and Lawrence JR: Salicylic acid: a link between aspirin, diet and the prevention of colorectal cancer. Q J Med 94: 445-448, 2001

40. Yu HG, Huang JA, Yang YN, et al: The effects of acetylsalicylic acid on proliferation, apoptosis, and invasion of cyclooxygenase- 2 negative colon cancer cells. Eur J Clin Invest 32: 838-846, 2002

41. Shiff SJ, Koutsos MI, Qiao L and Rigas B: Non-steroidal anti-inflammatory drugs inhibit the proliferation of colon adenocarcinoma cells: effects on cell cycle and apoptosis. Exp Cell Res 222: 179-188, 1996.

42. Whitacre CM, Zborowska E, Wilson JK and Berger NA: Detection of poly(ADP-ribose) polymerase cleavage in response to treatment with topoisomerase I inhibitors: a potential surrogate end-point to assess treatment effectiveness. Clin Cancer Res 5: 665-672, 1999.

43. Guo J, Verma UN, Gaynor RB, Frenkel EP and Becerra CR: Enhanced chemosensitivity to irinotecan by RNA interferencemediated down-regulation of the nuclear factor-kappaB p65 subunit. Clin Cancer Res 10: 3333-3341, 2004.

44. Paterson JR, Blacklock C, Campbell G, Wiles D and Lawrence JR: The identification of salicylates as normal constituents of serum: a link between diet and health? J Clin Pathol 51: 502-505, 1998.

45. Zerbini LF, Wang Y, Czibere A, et al: NF-kappa B-mediated repression of growth arrest- and DNA-damage-inducible proteins $45 \alpha$ and $\gamma$ is essential for cancer cell survival. Proc Natl Acad Sci USA 101: 13618-13623, 2004

46. Subbegowda R and Frommel TO: Aspirin toxicity for human colonic tumor cells results from necrosis and is accompanied by cell cycle arrest. Cancer Res 58: 2772-2776, 1998. 
47. Chan TA, Morin PJ, Vogelstein B and Kinzler KW: Mechanisms underlying non-steroidal anti-inflammatory drug-mediated apoptosis. Proc Natl Acad Sci USA 95: 681-686, 1998.

48. Williams JL, Nath N, Chen J, et al: Growth inhibition of human colon cancer cells by nitric oxide (NO)-donating aspirin is associated with cyclooxygenase- 2 induction and beta-catenin/T-cell factor signaling, nuclear factor-kappaB, and NO synthase 2 inhibition: implications for chemoprevention. Cancer Res 63: 7613-7618, 2003.

49. Rigas B: Novel agents for cancer prevention based on nitric oxide. Biochem Soc Trans 35: 1364-1368, 2007.
50. Tesei A, Zoli W, Fabbri F, et al: NCX 4040, an NO-donating acetylsalicylic acid derivative: efficacy and mechanisms of action in cancer cells. Nitric Oxide 19: 225-236, 2008.

51. Cheung GK, Duncanson P and Griffiths DV: Cyclisation reactions of 2-substituted benzoylphosphonates with trialkyl phosphites via nucleophilic attack on a carbonyl-containing ortho substituent. Tetrahedron 64: 2329-2338, 2008. 